\title{
Financial Literacy in Relation to Financial Management
}

\author{
ELISA P. TEJERO \\ elisatejero1973@gmail.com \\ https://orcid.org/0000-0001-6691-0574
}

LEAH WILFREDA RE PILONGO

leahechavez@universityofbohol.edu.ph

https://orcid.org/0000-0001-6380-1831

FRANCIS T. PAMARAN

ftpamaran@universityofbohol.edu.ph

https://orcid.org/0000-0001-5008-7210

\section{ABSTRACT}

Financial literacy is the capacity to analyze financial options, planning for the future, and responding appropriately to the events. This study intends to look into the association of financial literacy and financial management. The study utilized a quantitative approach employing descriptive normative survey of a modified survey questionnaire on financial literacy and financial management. The respondents of the study were the participants of the annual national conference of the Grace Gospel Church of Christ, which was held in Iloilo City on April 22-27, 2019 with 250 adult respondents. The questionnaire of Financial Literacy and Management Practices was used to measure financial literacy of individuals. The questionnaire considered the most critical personal finance factors in the measurement of the level of financial knowledge literacy and the financial decision-making on financial practices (Cronbach's Alpha results of Financial Literacy of 0.929 , Financial Management of 0.738 ). It was found that the Normality Test utilizing the Shapiro-Wilk yielded significant results in almost all items. Hence, non-parametric tests were used in the statistical runs. 
To ensure that the "do-no-harm," after complying the consenting forms, the researcher submitted to the Ethics Review Committee as the quality assurance that the researcher followed the ethics protocol. Financial Literacy and Management Practices significantly differ in each of the three groups in the congregation namely Leaders ( $t=11.567$, exact sig=0.000), Non-Leaders between financial literacy and management practices by rank in the congregation $(t=12.431$, exact sig $=0.000)$, and Members $(t=23.930$, exact sig=0.000). T-Test showed significant differences between the financial management practice on Personal/Family Budget and Financial Decision-Making.

Keywords: Financial Literacy, Financial Management, Quantitative Method, Visayas, Philippines

\section{INTRODUCTION}

Financial literacy is the fundamental knowledge and vocabulary which people need to internalize as the facts in the successful management of personal finances (Garman \& Forgue, 2000) to survive in modern society. People are more likely to achieve their financial goals with appropriate knowledge. Lack of personal financial knowledge limits personal financial management and may cause financial problems, resulting in lower financial well-being.

A need for adults to increase their level of knowledge and awareness of household finance is highly essential; such capability enables the person to manage personal financial responsibilities that they take on over a lifetime. Eventually, adults have the responsibility to manage household budgets that need to consider a great deal on income constraints. These constraints include buying goods, commodities, and services; monitoring financial accounts, handling credit cards, and saving. Also, investing in the foreseeable future, such as a child's college education or retirement, purchasing insurance to reduce risk, paying taxes, and seeking sound financial advice. It is a daunting task of being fully aware of personal finances to pace with the complexities of the financial world. Such posed an enormous challenge even among the most educated adults taking into consideration that the level of knowledge varies based on phases of the life-cycle or personal circumstances. The aftereffect of not being aware of even the basics about household financial matters can prove to be costly 
for adults. Such is imperative of making short-term or long-term financial decisions. It is this ever-changing and expensive financial environment that has stimulated significant interest in financial literacy in recent decades.

While it is essential to assess how financially literate people are, in practice, it is difficult to explore how people process financial information and make informed decisions about household finances. Perhaps because of this, relatively few researchers before 2000 incorporated financial literacy into theoretical models of saving and financial decision-making (Lusardi and Mitchell, 2011)

This growing concern led to increased research interest in how financial literacy affects the financial management of both adults and youth in the Grace Christian church and their financial capabilities. The young and the old population face an increasingly complex financial world. Economically disadvantaged youth and adults encounter the lack of financial knowledge and inability to access to mainstream financial institutions. Despite the scaling up of interest in youth's financial literacy, scarcity of comparable efforts to improve institutional access to financial institutions and services still happened. Instead of aiming for financial literacy, to strive for financial capability, a concept that builds on the writing is suggested.

Theories and models of saving and financial decision-making can be further expanded to incorporate financial knowledge, which is a form of Human Capital Theory. The process of endogenizing financial knowledge has high-essential implications for welfare aspects. It is also highly essential for prospective policies that intend to enhance levels of financial knowledge on the broader population (Lusardi, \& Mitchell, 2014). Furthermore, the efforts to measure better financial education are more likely to pay off. The outcomes of future studies are possible to be of interest. Examples include availing of loans, investing in health, and reversing mortgage patterns. Also, it includes when to claiming Social Security benefits and the foresight of coming up with a decision that all have far-reaching economic consequences.

Rational choice theory indicates that people rely on analytical calculations to attain outcomes that are within the bounds of their personal objectives. These decisions cater to individuals with the most prominent benefit or satisfaction, given the choices that are made available and are in line as well in their biggest self-interest. Furthermore, it assumes that all will work to lessen the losses. Further, the notion that since rational calculus deduces that human behavior, rationality, such will be the driving 
force when making a choice whose outcome will be maximizing the person's pleasure or profit. Minimal knowledge is closely associated with dismal results, which are conditional to participation.

Planned Behavior Theory stipulates that there is reasonably consistent evidence that financial education leads to increases in financial knowledge and more positive changes in financial attitudes, motivation, and planned behavior (Schuchardt, Hanna, Hira, Lyons, Palmer, and Xiao, 2009). Positive correlations have also been found between financial knowledge and financial practices (Hilgert, Hogarth, \& Beverly, 2003). This theory is used to understand and predict human behavior. This theory has been applied to online shopping, investing, and debt reducing behaviors (Xiao, 2008).

A need for institutions to involve in financial education curricula is highly needed. John Dewey, one of the early educators, made an emphasis on the importance of Learning by Doing. He argued that teaching should not be isolated from real-life experience (Harris, Denise \& Thomas, 1989; Dewey, 1938). It has to be taught what is the very basic of financial literacy and actualizing such by applying the principle in day-to-day life.

Another concept is the conventional economic approach to saving. Consumption decisions posit that a thoroughly well-informed and rational individual will consume less than what he earns, in times of high earnings. He will keep supporting consumption on instances when income falls. In this context, utilizing the works of Modigliani and Brumberg (1954), the consumer is to arrange his optimum saving and decreasing patterns to smoothen marginal utility in his lifetime. Various studies revealed that such a life cycle optimization process could be shaped by the preferences of the consumer, (like for instance, risk aversion and discount rates), the economic environment (like for instance, risky returns of investments and constraints due to liquidity), and social safety net benefits (like for instance, the availability and generosity of welfare schemes and Social Security income), among other features. Theoretical models incorporating such critical aspects of consumer behavior of financial management and the economic environment assume that people are capable of creating and executing saving and spending-down plans, all of those that required expertise in the handling of the financial markets, purchasing powerknowledge, and the ability to take on complex economic calculations. As we show below in more detail, this is far from right in the real world: very few people possess extensive financial knowledge conducive to making 
and executing elaborate plans (Lusardi \& Mitchell 2014).

The Sustainable Development Goals (SDGs) that was agreed at the General Assembly in 2015 at the United Nations embraced a wide-range set of global environmental, social and economic targets to promote the possible transition for a viable future of global citizens. There were six Sustainable Development Goals that focused on financial education that foresees a bigger and more significant difference in economic success. The challenge of ending poverty (SDG1) and how to take on it through financial inclusion. Ensure healthy lives and promote well-being for all at all ages (SDG3), emphasizing financial inclusion, and the opportunities afforded by longevity. The challenge of achieving quality education (SDG4), as to financial literacy, analyzing its impact on the youngest, lending them a voice, and listening to their testimonials to take their perspective on this matter. Progress toward gender equality (SDG5) in the access, knowledge, and use of financial services. Innovation and infrastructure (SDG9), the impact of digital transformation on financial education and consumer security. Lastly, the fight against climate change (SDG13) through socially responsible investments.

The study of Jurevičienè \& Ivanova, (2013), household finance explicitly explains the possibility of how he manages his financial decisions to ensure financial security and growth of wealth of a household. An example is the complexity of financial products that has prompted the growing interest of Lithuanian families in personal finance management. Behavioral finance admits that psychological characteristics (such as risk aversion, regret, overconfidence) play an essential role in the financial management of a household. As a consequence, it may avoid financial weaknesses, which could lead to improvements in financial decisionmaking and the growth of wealth of a home. It takes education in this area that should be popularized, as only a small percentage of households are knowledgeable and can effectively use available financial information.

Huston 2010 posited that financial literacy (or financial knowledge) is a standard input to create a model. It is a need for financial education; thus, explains the variation in financial outcomes. Defining and appropriately measuring financial literacy is essential to understand the educational impact as well as barriers to practical economic choice. As an offshoot of the conceptualized definition, financial literacy is an additional application dimension. It connotes that a person must have the capability and confidence in utilizing his/her financial knowledge to come up with financial 
decisions. When coming up with an instrument to measure financial literacy, it is essential not only to determine if a person is aware of the information, but it also means his/her capacity to apply such appropriately (Huston 2010).

As pointed out by Jonson and Sherraden 2007, financial literacy is very positive but not an all-encompassing idea. A person's active involvement in economic life can maximize life chances and enable him/ her to enjoy a fulfilling life as he or she can manage his finances well. This matter requires knowledge and competencies, the ability to act on that knowledge, and opportunity to perform. Furthermore, such a move is more likely to happen when people can convert knowledge into action. In several countries, it mushroomed that curriculum are required to integrate concepts of personal finance into core subjects, namely Mathematics, Social Studies, and Economics.

Vitt, Anderson, Kent, Lyter, Siegenthaler, and Ward (2000) define financial literacy as the ability to read, analyze, manage, and communicate about the personal financial conditions that affect material well-being. It includes the ability of one to reflect on choices on their finances, engages in discussions on issues on finances without being uneasy. A need to plan for the future and respond competently to life events that affect everyday financial decisions, such include development in the general economy to attain sound financial management.

A person can come up with a deeper understanding of his financial capability. The measures should include assessments, not just of financial knowledge, but also financial decision making, participation in financial institutions, and the level of a person's debts and savings. It is essential to assess these measures for minority and lower-income households who across history have had limited access to mainstream financial services (Hogarth, Hogarth, Beverly, \& Hilgert, 2003).

As pointed out by Lusardi \& Mitchelli (2007), studies were conducted to investigate the financial illiteracy causes. It aimed to get explanations on the lack of retirement planning. Moreover, it sought for answers on reasons for several households who are close to retiring age. However, they have issues with saving. Reviews revealed that several families were not familiar with the most fundamental concepts needed to arrive into sound decision to save and invest. This kind of financial illiteracy is widespread. Both the young and older generations all over the world appeared to be under-informed about basic financial concepts, with far- 
reaching implications for saving, retirement planning, mortgages, and other decisions. Governments and non-profit organizations undertook various initiatives to improve the level of financial literacy. Other countries' experiences that include Japan's saving campaign and the privatization of the Swedish pension program offered insights into greater possibilities for financial literacy and saving plans.

Given the scenario and current realities of the high-risk and globalized marketplace, there is a need for people to come up with well-informed decisions financially. Current research conducted internationally found that financial illiteracy is highly-relevant in rapidly changing markets and those who are well-developed. It was further found that women are less financially literate than men, and so with the young and the old, they are less financially literate than the middle-aged. Moreover, the more educated people are more financially knowledgeable. Most importantly, more people can plan their retirement when they are financially literate. The estimates of instrumental financial variables show that the effects of financial literacy on retirement planning tend to be underestimated. In sum, globally, financial literacy is critical to retirement security (Lusardi \& Mitchelli, 2007).

The study of Mahdavi (2012) found a connection between financial literacy and parental background. In such cases, the educational experience of the father is positively associated with their daughters' financial literacy. It goes to show that financial literacy may undoubtedly have its start in the family, most likely, where children observed the saving behavior and investing habits of parents, or more likely determined by receiving financial education from parents (Chiteji and Stafford 1999).

\section{THE PROBLEM}

\section{Statement of the Problem.}

This study investigated the level of financial literacy in relation to financial management among the parishioners of Grace Gospel Church who attended the Annual Conference at lloilo City, Philippines, April 20-27, 2019. The findings of the study would serve as the bases for the proposed program for the said churchgoers.

Specifically, it would answer the following sub-problems:

1. What is the level of financial literacy among the respondents?

2. What is a level of financial management practices of the respondents 
as to the following:

2.1 personal/family budget; and,

2.2 financial decision making?

3. Is there a significant degree of relationship between the profile of the respondents and the following:

3.1 financial literacy;

3.2 financial management; and,

4. Is there a significant degree of correlation among the following:

4.1 financial literacy and management;

5. Is there a significant degree of difference between the perspectives of the pastors and members on the financial literacy and financial management;

6. Is there a significant degree of difference between the two dimensions of financial management?

7. Based on the findings, what proposed program can be crafted for the parishioners of the Grace Gospel Church of the Philippines?

Null Hypotheses. The study had the following null hypotheses for acceptance or rejection:

1. There is no significant degree of relationship between the profile of the respondents and the following:

a. financial literacy

b. financial management

2. There is no significant degree of correlation on financial literacy and management.

3. There is no significant degree of difference between the perspectives of the pastors and members on financial literacy and management.

4. There is no significant degree of difference between the two dimensions of financial management.

\section{RESEARCH METHODOLOGY}

The study utilized a quantitative approach employing descriptive normative survey of a modified survey questionnaire on financial literacy and financial management. It focused on planning to solve a real-world problem, and the results can be applied in real decision-making situations. The modification of the tool was intended to contextualize the specific items on personal financial management practices and decision-making 
that increased surface validity and reliability.

Environment. The study was conducted in an Annual Conference among church leaders and members of Grace Gospel Church of the Philippines on April 23-27, 2019 in Pontavilla Resort, Arevalo, Iloilo City, Philippines. The participants came from various places in the said country.

Respondents. The respondents of the study were the participants of the annual national conference of the Grace Gospel Church of Christ, which was held in Iloilo City on April 22-27, 2019. An estimated number of 500 conference participants and those who were willing to undertake the survey that included as part of the total estimates of 250 adult respondents.

Instrument. A modified questionnaire of Financial Literacy and Management Practices was used to measure financial literacy of individuals which was based from the Financial Literacy Survey: 2016 of the Central Council for Financial Services Information Secretariat: Public Relations Department, Bank of Japan. The questionnaire contained two essential parts: first was the most critical personal finance factors in the measurement of the level of financial knowledge literacy. The second part was the financial decision-making in financial practices.

The tool was pilot tested with 15 respondents with a similar sociodemographic profile of the actual respondents of this particular study. Then, the data, after being encoded in excel, were being processed using Cronbach's Alpha Test in the SPSS 24. It was found that items on Financial Literacy yielded 0.929 , the value indicated high-level of internal consistency. The Cronbach's Alpha on Financial Management on Personal/Family Budget result indicated the value of 0.738 ; such showed an acceptable level of internal consistency.

The Cronbach's Alpha on Financial Management on Decision-Making yielded a 0.774 value, which indicates an acceptable level of internal consistency. Upon finding out that the reliability and internal consistency of all items were ensured, the researchers pursued the data gathering.

The answers of the respondents are interpreted as follows:

\begin{tabular}{|c|c|c|}
\hline \multicolumn{3}{|l|}{ Financial Literacy } \\
\hline & Descriptors & Interpretation \\
\hline Strongly Agree & Fully accede to the statement & High Financial Literacy \\
\hline Moderately Agree & Somewhat accede to the statement & Moderate Financial Literacy \\
\hline Moderately Disagree & Somewhat negate to the statement & Less Financial Literacy \\
\hline Strongly Disagree & Fully negate to the statement & Least Financial Literacy \\
\hline
\end{tabular}




\begin{tabular}{|c|c|c|}
\hline \multicolumn{3}{|c|}{ Financial Management Practices } \\
\hline & Descriptors & Interpretation \\
\hline Strongly Agree & Very Evident & High Financial Management \\
\hline Moderately Agree & Moderately Evident & $\begin{array}{l}\text { Moderate Financial } \\
\text { Management }\end{array}$ \\
\hline Slightly Agree & Less Evident & Less Financial Management \\
\hline Disagree & Least Evident & No Financial Management \\
\hline
\end{tabular}

In the Personal/Family Budget Financial Management dimension, items, 1, 2, 3, 4, 5, 6, 7 and 9 had reversed valence. In the Decision-Making Financial Management dimension, the reversed valence happened at items 5,8 , and 9.

Furthermore, the determination of the type of statistical measures, whether to use parametric or non-parametric tests, was determined by undertaking the Normality Test. It was used to check if the data is normally distributed or skewed. The Normality Test utilizing the Shapiro-Wilk yielded significant results in almost all items. Hence, non-parametric tests were used in the statistical runs.

Ethical Considerations of Research. To ensure that the study observed the "do-no-harm," the researchers secured voluntary consent from the respondents by letting them affix their signatures in the consenting forms. The researchers assured the observance of complete anonymity on the processing of data. It secured the approval of the Ethics Review Committee for the conduct of the study.

Statistical Treatment. The gathered data were coded and processed using Statistical Package for Social Sciences (SPSS) Version 25. The profile of the respondents, frequencies, and simple percentages were used. The extent of Financial Literacy and Financial Management in both the Personal/Family Budget, and Decision Making, the Frequency Counts and Weighted Mean were used. To check if the data were normally distributed, the Shapiro-Wilk was used.

The association between Profile and Financial Literacy and Financial Management; Weighted Mean, Frequency Counts, Percentages, Freeman-Halton Test, Chi-Square Test, and Fisher's Exact Test were used. Bootstrapping in SPPSS was used as a procedure in resampling in such a way that multiple sub-samples of the same size as the original sample are randomly drawn to come up with data for empirical investigation of the variability of parameter estimates and indices of fit (Byrne, 2010). Pearson 
Product Moment Correlation was used in testing the correlation between Financial Literacy and Financial Management. Paired T-Test was used in running a test of the difference between Financial Literacy and Financial Management, Personal/Family Budget and Financial Decision-Making, all by Rank in the Congregation.

\section{RESULTS AND DISCUSSION}

\section{Level of Financial Literacy}

Table 1 presents the Level of Financial Literacy among the respondents with High Financial Literacy (3.57). All items are considered High in Financial Literacy among the respondents.

Table 1. Level of Financial Literacy among the respondents $(n=250)$

\begin{tabular}{|c|c|c|c|}
\hline Items & Mean & Std. Deviation & Interpretation \\
\hline $\begin{array}{l}\text { 3. I am aware that the expenses should } \\
\text { not exceed the earnings. }\end{array}$ & 3.74 & 0.529 & $\begin{array}{l}\text { High Financial } \\
\text { Literacy }\end{array}$ \\
\hline $\begin{array}{l}\text { 4. I am aware that it spells trouble } \\
\text { when the 'wants' are prioritized over the } \\
\text { 'needs.' }\end{array}$ & 3.74 & 0.489 & $\begin{array}{l}\text { High Financial } \\
\text { Literacy }\end{array}$ \\
\hline $\begin{array}{l}\text { 10. I am aware of the need to look into } \\
\text { the long-term investments with financial } \\
\text { experts in planning the future. }\end{array}$ & 3.67 & 0.586 & $\begin{array}{l}\text { High Financial } \\
\text { Literacy }\end{array}$ \\
\hline $\begin{array}{l}\text { 1. I keep track of the prices of basic } \\
\text { commodities (rice, fish, vegetables, } \\
\text { among others) in the market. }\end{array}$ & 3.63 & 0.538 & $\begin{array}{l}\text { High Financial } \\
\text { Literacy }\end{array}$ \\
\hline $\begin{array}{l}\text { 9. I am aware that there is a need to } \\
\text { look into the cost of every transaction } \\
\text { (jewelry, car, land among others). }\end{array}$ & 3.6 & 0.639 & $\begin{array}{l}\text { High Financial } \\
\text { Literacy }\end{array}$ \\
\hline $\begin{array}{l}\text { 5. I am aware of the need to prepare for } \\
\text { my retirement plan. }\end{array}$ & 3.52 & 0.648 & $\begin{array}{l}\text { High Financial } \\
\text { Literacy }\end{array}$ \\
\hline $\begin{array}{l}\text { 2. I keep track on the prices of gasoline } \\
\text { among oil players on any of the various } \\
\text { media (radio, television and online } \\
\text { news). }\end{array}$ & 3.49 & 0.622 & $\begin{array}{l}\text { High Financial } \\
\text { Literacy }\end{array}$ \\
\hline $\begin{array}{l}\text { 8. I am aware of the repercussions of } \\
\text { unpaid debts/loans/credits cards/POs } \\
\text { pertaining to simple and compounded } \\
\text { interests. }\end{array}$ & 3.48 & 0.787 & $\begin{array}{l}\text { High Financial } \\
\text { Literacy }\end{array}$ \\
\hline $\begin{array}{l}\text { 7. I am aware of the conditions of } \\
\text { acquiring loans (financial or in kind). }\end{array}$ & 3.41 & 0.827 & $\begin{array}{l}\text { High Financial } \\
\text { Literacy }\end{array}$ \\
\hline
\end{tabular}


6. I am aware of the conditions of acquiring credit cards.

3.36

0.872

High Financial

Literacy

Composite Mean

3.57

0.431

High Financial Literacy

Table 1 presents a tie of two items which are items on "I am aware that the expenses should not exceed the earnings," and "I am aware that it spells trouble when the 'wants' are prioritized over the 'needs'" shared the topmost rank of 1.5 with weighted mean 3.74. It is followed by the item on "I am aware of the need to look into the long-term investments with financial experts in planning the future" with the Weighted Mean of 3.67.

Items at the bottom of the rank are as follows, 10th rank is the item on "I am aware of the conditions of acquiring credit cards" with the Weighted Mean of 3.36. It is followed by the item on "I am aware of the conditions of acquiring loans (financial or in-kind)" with the Weighted Mean of 3.41. Third from the bottom is the item on "I am aware of the repercussions of unpaid debts/loans/credits cards/POs pertaining to simple and compounded interests" with the Weighted Mean of 3.48 .

\section{Level of financial management practices of the respondents as to the following:}

\subsection{Personal/Family Budget}

As to the level of Personal/Family Budget management in the perspective of the respondents, Table 2 reveals that Composite Mean is 2.41 , which has the interpretation of Less Financial Management.

Table 2.1 Level of personal/family budget management of the respondents

$(n=250)$

\begin{tabular}{lccl}
\hline Items & Mean & Std. Deviation & Interpretation \\
\hline $\begin{array}{l}\text { 8. I ensured to secure the family } \\
\text { budget and expenditures. }\end{array}$ & 3.28 & 0.777 & $\begin{array}{l}\text { High Financial } \\
\text { Management }\end{array}$ \\
$\begin{array}{l}\text { 10. I look into actualizing the financial } \\
\text { plan to secure the future. }\end{array}$ & 3.25 & 0.697 & $\begin{array}{l}\text { High Financial } \\
\text { Management }\end{array}$ \\
$\begin{array}{l}\text { 6. I borrow money to buy my basic } \\
\text { needs. }\end{array}$ & 2.55 & 0.99 & $\begin{array}{l}\text { Moderate Financial } \\
\text { Management }\end{array}$ \\
$\begin{array}{l}5 . \quad \text { I can hardly buy the basic } \\
\text { commodities for my family. }\end{array}$ & 2.3 & 1.019 & $\begin{array}{l}\text { Less Financial } \\
\text { Management }\end{array}$ \\
\hline
\end{tabular}


1. I could hardly pay my bills before or on the due dates.

3. I cannot set aside chunk of the income for savings.

2. I have a hard time making both ends meet in my finances.

4. It is too difficult to save with the income we have.

7. The family income is not enough to buy our basic needs.

9. I resort to impulse buying on things which are not necessary.

Composite Mean
2.29

0.973

2.27

0.972

2.17

0.891

2.17

0.956

2.14

1.72

2.41
Less Financial

Management

Less Financial

Management

Less Financial

Management

Less Financial

Management

Less Financial

Management

Least Financial

Management

Less Financial

Management

Table 2 depicts the top two ranked items that had a High Level of Financial Management. Rank one is an item on "I ensured to secure the family budget and expenditures" with Weighted Mean of 3.28. It is followed by the item on "I look into actualizing the financial plan to secure the future." The third rank item is on "I borrow money to buy my basic needs," which has Moderate Level of Financial Management.

The most bottom answer is the item on "I resort to impulse buying on things which are not necessary" with Weighted Mean of 1.72, which has the interpretation of Least Financial Management. Second from the bottom is the item on "The family income is not enough to buy our basic needs, "which has the Weighted Mean of 2.14, which has the interpretation of Less Financial Management. The third from the bottom is a tie of two items, namely, "It is too difficult to save with the income we have" and "I have a hard time making both ends meet in my finances" with the Weighted Mean of 2.17 which means Less Financial Management. As depicted by Joo (2013), Financial management includes proper behavior with various personal finances topics. To become financially healthy, individuals need to exhibit desirable behaviors with cash management, credit, and debt management, planning for different life cycle events, and consumerism. 


\subsection{Financial decision-making}

Table 2.2 Level of financial decision-making of the respondents

$$
(n=250)
$$

\begin{tabular}{|c|c|c|c|}
\hline Items & Mean & $\begin{array}{l}\text { Std. } \\
\text { Deviation }\end{array}$ & Interpretation \\
\hline $\begin{array}{l}\text { 7. I am careful of entering into contracts when } \\
\text { money is involved (be it lending or borrowing } \\
\text { money, or financial investments). }\end{array}$ & 3.26 & 0.788 & $\begin{array}{l}\text { High financial } \\
\text { management }\end{array}$ \\
\hline $\begin{array}{l}\text { 6. I keep track of the expenses incurred to } \\
\text { ensure to live within the means. }\end{array}$ & 3.16 & 0.859 & $\begin{array}{l}\text { Moderate } \\
\text { financial } \\
\text { management }\end{array}$ \\
\hline 4. I avoid incurring debts as much as possible. & 2.98 & 0.942 & $\begin{array}{l}\text { Moderate } \\
\text { financial } \\
\text { management }\end{array}$ \\
\hline $\begin{array}{l}\text { 2. I bought products after spending some time } \\
\text { to compare the brands of products before } \\
\text { acquiring. }\end{array}$ & 2.96 & 0.882 & $\begin{array}{l}\text { Moderate } \\
\text { financial } \\
\text { management }\end{array}$ \\
\hline $\begin{array}{l}\text { 1. I paid my insurance coverage to gain financial } \\
\text { security (life, health and security plan). }\end{array}$ & 2.95 & 0.966 & $\begin{array}{l}\text { Moderate } \\
\text { financial } \\
\text { management }\end{array}$ \\
\hline $\begin{array}{l}\text { 3. I pay quality education for myself or my } \\
\text { children to prepare for our future. }\end{array}$ & 2.92 & 0.958 & $\begin{array}{l}\text { Moderate } \\
\text { financial } \\
\text { management }\end{array}$ \\
\hline $\begin{array}{l}\text { 10. I purchased risk assets such as stocks or } \\
\text { investment trusts to ensure the future of the } \\
\text { family. }\end{array}$ & 2.7 & 0.986 & $\begin{array}{l}\text { Moderate } \\
\text { financial } \\
\text { management }\end{array}$ \\
\hline 9. I resort to online buying spree. & 2.54 & 0.957 & $\begin{array}{l}\text { Moderate } \\
\text { financial } \\
\text { management }\end{array}$ \\
\hline $\begin{array}{l}\text { 5. At a certain time, I became a victim of debt } \\
\text { trap (compounded interests of unpaid loans/ } \\
\text { credit card/PO). }\end{array}$ & 2.44 & 0.993 & $\begin{array}{l}\text { Less financial } \\
\text { management }\end{array}$ \\
\hline 8. I resort to impulse buying. & 2.36 & 0.956 & $\begin{array}{l}\text { Less financial } \\
\text { management }\end{array}$ \\
\hline Composite Mean & 2.83 & 0.352 & $\begin{array}{l}\text { Moderate } \\
\text { financial } \\
\text { management }\end{array}$ \\
\hline
\end{tabular}


Table 2.2 depicts the respondents' Financial Decision-Making of the respondents where the Composite Mean is 2.83 with the interpretation that they have Moderate Financial Management.

Top rank answers are as follows, "I am careful of entering into contracts when money is involved (be it lending or borrowing money, or financial investments)" with a Weighted Mean of 3.26 which is considered as High in Financial Management. The second to third ranks have Moderate Financial Management interpretations. Occupying the second rank is, "I keep track of the expenses incurred to ensure to live within the means" with the Weighted Mean of 3.16, and the item on "I avoid incurring debts as much as possible" with the Weighted Mean of 2.98 is ranked 3 (See Table 3.2).

Bottom ranks are items on "I resort to impulse buying" with the Weighted Mean of 2.36, which has Less in Financial Management interpretation. Second from the bottom is the item on "At a certain time, I became a victim of debt trap (compounded interests of unpaid loans/credit card/PO)" with the Weighted Mean of 2.44. The third from the bottom is "I purchased risk assets such as stocks or investment trusts to ensure the future of the family" with the Weighted Mean of 2.70. The items from second and third from the bottom have Moderate Financial Management Interpretation (See Table 2.2).

\section{Degree of association between the profile of the respondents and the following:}

\subsection{Financial Literacy}

Table 3.1 depicts the Summary Table of the relationship of profile to the Level of Financial Literacy of the respondents using Freeman-Halton Test. 
Table 3.1. Summary table of the degree of relationship between profile and financial literacy of the respondents

\begin{tabular}{|c|c|c|c|c|c|}
\hline Variables & $\begin{array}{l}\text { Freeman-Halton } \\
\text { Test Results }\end{array}$ & Df & P-Value & Results & Decisions \\
\hline $\begin{array}{l}\text { 1. Age Group and } \\
\text { Financial Literacy }\end{array}$ & 12.322 & 4 & 0.010 & Significant & Reject the $\mathrm{H} 0$ \\
\hline $\begin{array}{l}\text { 3. Sex and } \\
\text { Financial Literacy }\end{array}$ & 4.871 & 2 & 0.093 & Insignificant & $\begin{array}{l}\text { Failed to reject } \\
\text { the } \mathrm{HO}\end{array}$ \\
\hline $\begin{array}{l}\text { Civil Status and } \\
\text { Financial Literacy }\end{array}$ & 8.123 & 2 & 0.014 & Significant & Reject the $\mathrm{HO}$ \\
\hline $\begin{array}{l}\text { Highest Educational } \\
\text { Attainment and } \\
\text { Financial Literacy }\end{array}$ & 26.486 & 8 & 0.000 & Significant & Reject theHO \\
\hline $\begin{array}{l}\text { Employment Status } \\
\text { and Financial } \\
\text { Literacy }\end{array}$ & 18.206 & 4 & 0.000 & Significant & Reject theHO \\
\hline $\begin{array}{l}\text { Rank in the } \\
\text { Congregation and } \\
\text { Financial Literacy }\end{array}$ & 8.268 & 4 & 0.06 & Insignificant & $\begin{array}{l}\text { Failed to reject } \\
\text { the } \mathrm{HO}\end{array}$ \\
\hline
\end{tabular}

Table 3.1 reveals that using the Freeman-Halton test; the age grouping is significantly associated (Freeman-Halton Test=12.322, $\mathrm{df}=4$, Exact Sig $(2$-sided $)=0.010)$ with the level of financial literacy. This result means that age grouping is associated with financial literacy. This finding agrees with the study of Atkinson and Messy (2012). They found that age grouping is associated with financial literacy. Middle-age has a higher level of financial literacy, while the oldest and youngest respondents are more likely to have no high scores.

As to the association between the level of literacy and the sex of the respondent, the Freeman-Halton test result shows no association (Freeman-Halton Test $=4.871, \mathrm{df}=2$, Exact Sig (2-sided) $=0.093$ ) between the respondents' financial literacy level and sex (See Table 3.1). This finding means that being male or female has no bearing on the level of financial literacy. Such findings negated other common patterns that were found in the study of Lusardi, \& Mitchell, (2011) titled Financial literacy around the world: an overview. It claimed that women are less financially literate compared to men, and they are aware of such shortfall. In this particular 
study, the age 30-59 registered High Financial Literacy compared to the other age groups; however, it is not statistically significant.

A statistically significant association (Freeman-Halton Test $=8.123$, $\mathrm{df}=2$, Exact Sig $(2$-sided $)=0.014$ ) exists between financial literacy and civil status (see Table 3.1). The data in Table 5.1c shows that married/ widowed/widowers have heightened levels of financial literacy compared to their non-married counterparts.

The bivariate analysis was used to explores whether there is an association between educational attainment and financial literacy level.

The Freeman-Halton Test revealed a very strong, statistically significant association (Freeman-Halton Test=26.486, $\mathrm{df}=8$, Exact Sig $(2$-sided $)=0.000)$ between financial literacy and education. This result means that $\mathrm{Ho}$ is rejected at .05 level, which consequently means that there is indeed a relationship between educational attainment and financial literacy. College and Post Graduate levels showed higher financial literacy. These particular findings contradict with the results of the study of Lusardi, \& Mitchell, (2011) where it stipulated that even if the more that educated people are more informed, however, education is far from being a perfect proxy for financial literacy. It was found that a positive relationship between education and financial literacy. It follows that those who have higher education levels are more likely to exhibit positive financial behaviors/ management as well as advanced levels of financial literacy (Atkinson \& Messy 2012).

A statistically significant association (Freeman-Halton Test $=18.206$, $\mathrm{df}=4$, Exact Sig $(2$-sided $)=0.000$ ) exists between financial literacy and employment status of the respondents. The employment status has a significant relationship on the levels of financial literacy (See Table 3.1). The employed have high financial literacy among the rest of the respondents. This finding affirms the study of Hassan Al-Tamimi, \& Anood Bin Kalli, (2009) upon which the key findings provide the financial literacy at the lowest levels were associated with people who were unemployed or unskilled workers, and people with low income, and those at both extremes of the age profile.

A statistically insignificant association (Freeman-Halton Test $=8.268$, $\mathrm{df}=4$, Exact Sig (2-sided $)=0.060)$ between the rank in the congregation and the level of financial literacy among the respondents is revealed. It is in consonance to what is hypothesized, rank, or position in the church does not necessarily imply higher financial literacy. 


\subsection{Financial Management}

\section{A. Personal/Family Budget}

Table 3.2 illustrates the summary table of the profile and personal/ family budget management of the respondents.

Table 3.2 Summary table of profile and personal/family budget management of the respondents

\begin{tabular}{|c|c|c|c|c|c|}
\hline Variables & $\begin{array}{l}\text { Freeman- } \\
\text { Halton Test } \\
\text { Results/ } \\
\text { Fisher Exact } \\
\text { Test Result }\end{array}$ & Df & P-Value & Results & Decisions \\
\hline $\begin{array}{l}\text { 1. Age Group and } \\
\text { Personal/Family Budget } \\
\text { Management }\end{array}$ & 23.343 & 6 & 0.000 & Significant & Reject the $\mathrm{HO}$ \\
\hline $\begin{array}{l}\text { 3. Sex and Personal/ } \\
\text { Family budget } \\
\text { Management }\end{array}$ & 6.421 & 3 & 0.094 & Insignificant & $\begin{array}{l}\text { Failed to reject } \\
\text { the } \mathrm{HO}\end{array}$ \\
\hline $\begin{array}{l}\text { Civil Status and } \\
\text { Personal/Family Budget } \\
\text { Management }\end{array}$ & 7.477 & 3 & 0.056 & Insignificant & $\begin{array}{l}\text { Failed to reject } \\
\text { the } \mathrm{HO}\end{array}$ \\
\hline $\begin{array}{l}\text { Highest Educational } \\
\text { Attainment and } \\
\text { Personal/Family Budget } \\
\text { Management }\end{array}$ & 15.701 & 9 & 0.053 & Insignificant & $\begin{array}{l}\text { Failed to reject } \\
\text { the } \mathrm{HO}\end{array}$ \\
\hline $\begin{array}{l}\text { Employment Status and } \\
\text { Personal/Family Budget } \\
\text { Management }\end{array}$ & 13.15 & 6 & 0.036 & Significant & Reject theHO \\
\hline $\begin{array}{l}\text { Rank in the Congregation } \\
\text { and Personal/Family } \\
\text { Budget Management }\end{array}$ & 6.525 & 6 & 0.337 & Insignificant & $\begin{array}{l}\text { Failed to reject } \\
\text { the } \mathrm{HO}\end{array}$ \\
\hline
\end{tabular}

There is a significant statistical association (Freeman-Halton Test $=23.343$, df $=6$, Exact Sig $(2$-sided $)=0.000)$ that exists between age groupings and financial management of the respondents (see Table 3.2). The data shows that age 60 and older have the highest financial management compared to the rest of the respondents. Such findings disagree with the results of the study conducted by Gecas (1989). He asserted that in most cross-sectional analyses of different age groups document a curvilinear pattern such that the sense of control (or "self- 
efficacy") that includes financial management increases through early adulthood, peaks during middle age, and then becomes lower among successively older age groups.

There is no statistically significant association (X2 Test $=6.421$, $d f=3$, Exact Sig $(2$-sided $)=0.094)$ that exists between sex and financial management in terms of personal/family budget of the respondents. Hence, age groupings have nothing to do with levels of financial management in this sub-dimension (See Table 3.2).

The data revealed that there is no statistically significant relationship (Fisher's Exact Test $=7.477, \mathrm{df}=3$, Exact Sig (2-sided) $=0.056)$ that exists between Civil Status and Personal/Family Budget Financial Management Level of the respondents. Hence, Civil Status has nothing to do with Personal/Family Budget Financial Management Level (See Table 3.2).

Furthermore, the data revealed that there is no significant statistical relationship (Freeman-Halton Test $=15.701$, $d f=9$, Exact Sig $(2$-sided $)=0.053$ ) between educational attainment and personal/family budget financial management (See Table 3.2). This result means that the educational attainment has nothing to do with personal/family budget financial management.

The data revealed that there is a statistically significant relationship (Freeman-Halton Test=13.150, $\mathrm{df}=6$, Exact Sig (2-sided) $=0.036$ ) between Employment Status and Levels of Financial Management pertaining to Personal/Family Budget (See Table 3.2).

Data revealed that there is no statistically significant relationship (Freeman-Halton Test $=6.525, \mathrm{df}=6$, Exact Sig (2-sided) $=0.337$ ) between Ranks of the respondents in the Congregation and their Financial Management Level in Personal/Family Budget (See Table 3.2).3.3 Profile and Financial Decision-making

\section{B. Financial Decision-making}

Table 3.3 shows the summary of the degree of associations between profile and financial decision-making. 
Table 3.3 Summary table of profile and financial decision-making of the respondents

\begin{tabular}{|c|c|c|c|c|c|}
\hline Variables & $\begin{array}{l}\text { Freeman- } \\
\text { Halton Test } \\
\text { Results }\end{array}$ & Df & P-Value & Results & Decisions \\
\hline $\begin{array}{l}\text { 1. Age Group and } \\
\text { Financial Decision- } \\
\text { Making }\end{array}$ & 34.717 & 4 & 0.000 & Significant & $\begin{array}{l}\text { Reject the } \\
\mathrm{HO}\end{array}$ \\
\hline $\begin{array}{l}\text { 3. Sex and Financial } \\
\text { Decision-Making }\end{array}$ & 0.673 & 2 & 0.712 & Insignificant & $\begin{array}{l}\text { Failed to } \\
\text { reject the } \\
\mathrm{HO}\end{array}$ \\
\hline $\begin{array}{l}\text { Civil Status and } \\
\text { Financial Decision- } \\
\text { Making }\end{array}$ & 12.523 & 2 & 0.002 & Significant & $\begin{array}{l}\text { Reject the } \\
\mathrm{HO}\end{array}$ \\
\hline $\begin{array}{l}\text { Highest Educational } \\
\text { Attainment and } \\
\text { Financial Decision- } \\
\text { Making }\end{array}$ & 13.884 & 8 & 0.053 & Insignificant & $\begin{array}{l}\text { Failed to } \\
\text { reject the } \\
\mathrm{HO}\end{array}$ \\
\hline $\begin{array}{l}\text { Employment Status } \\
\text { and Financial Decision- } \\
\text { Making }\end{array}$ & 4.348 & 4 & 0.364 & Insignificant & $\begin{array}{l}\text { Failed to } \\
\text { reject the } \\
\mathrm{HO}\end{array}$ \\
\hline $\begin{array}{l}\text { Rank in the } \\
\text { Congregation and } \\
\text { Financial Decision- } \\
\text { Making }\end{array}$ & 5.782 & 4 & 0.0 .204337 & Insignificant & $\begin{array}{l}\text { Failed to } \\
\text { reject the } \\
\mathrm{HO}\end{array}$ \\
\hline
\end{tabular}

The data further revealed that there is a statistically significant relationship (Freeman-Halton Test $=34.717, \mathrm{df}=4$, Exact Sig $(2-$ sided $)=0.000)$ that exists between Age-Groups and Levels of Personal/ Family Budget Financial Management (See Table 3.3). Further, the data reflected that the majority (75.6 percent) has a Moderate Level of Financial Literacy. The age level of 30-59 years of age group has the highest literacy level. Such findings agree with the results of the study conducted by Gecas (1989). He asserted that in most cross-sectional analyses of different age groups documented a curvilinear pattern. The sense of control (or "selfefficacy") that includes financial management increases through early adulthood. Further, it peaks during middle age and then becomes lower among successively older age groups.

The data revealed that there is no statistically significant relationship (Fisher's Exact Test $=0.673$, $d f=2$, Exact Sig $(2$-sided $)=0.712$ ) that exists between sex and Financial Management in the Decision-Making process (See Table 3.3). The results mean that sex has nothing to do 
with the financial management of the respondents. This particular finding contradicts of the study of Atkinson and Messy (2012). The study revealed that in several countries, such as Albania, Armenia, South Africa women are less likely to gain high scores for financial behavior than men.

The data revealed that there is a statistically significant relationship (X2 Test=12.523, df=2, Exact Sig (2-sided)=0.002) that exists between Civil Status and Financial Decision-Making Literacy (See Table 3.3). The civil status matters in terms of the Level of Financial Decision-Making Literacy of the respondents. The married/widow/widower group has higher financial decision-making management among the respondents.

The data revealed that there is no statistically significant relationship (Freeman-Halton Test $=13.884, \mathrm{df}=8$, Exact Sig $(2$-sided $)=0.053)$ that exists between Educational Attainment and Financial Budget Management (See Table 3.3). It means that the levels of educational qualification have nothing to do with financial budget management.

The data revealed that there is no statistically significant relationship $(\mathrm{X} 2$ Test $=4.348, \mathrm{df}=4$, Exact Sig (2-sided $)=0.364)$ that exists between the Employment Status and Financial Decision-Making Management levels (See Table 3.3). The Employment Status of the respondents has nothing to do with their Financial Decision-Making Management Levels.

Data revealed that there is no statistically significant relationship (Freeman-Halton Test $=5.782, \mathrm{df}=4$, Exact Sig $(2$-sided $)=0.204)$ that exists between Position in the Congregation to the Financial Level of Budget Management (See Table 3.3).

\section{Degree of correlation of financial literacy and management practices}

Table 4.1 examines the correlation between financial literacy and the financial management practices in Personal or Family Budget, Financial Decision Making, and the Overall Financial Management Practices. Table 4.1 shows the correlation coefficient and the exact significance (2-tailed) using the original 250 sample size and the bootstrapped value $(n=1,000)$ to correct for the non-normal data distribution. 


\begin{tabular}{|c|c|c|c|c|c|c|}
\hline & \multicolumn{2}{|c|}{$\begin{array}{l}\text { Original sample } \\
\qquad(n=250\end{array}$} & \multicolumn{4}{|c|}{ Bootstrapped $(n=1,000)$} \\
\hline & \multirow{2}{*}{$\begin{array}{l}\text { Pearson } \\
\text { Corr. }\end{array}$} & \multirow{2}{*}{$\begin{array}{c}\text { Sig } \\
\text { (2-tailed) }\end{array}$} & \multirow{2}{*}{ Bias } & \multirow{2}{*}{$\begin{array}{l}\text { Std. } \\
\text { Error }\end{array}$} & \multicolumn{2}{|c|}{ 95\% Confidence Int. } \\
\hline & & & & & Lower & Upper \\
\hline $\begin{array}{l}\text { Personal or Family } \\
\text { Budget }\end{array}$ & .054 & .393 & .000 & .057 & -.051 & .171 \\
\hline $\begin{array}{l}\text { Financial Decision } \\
\text { Making }\end{array}$ & .036 & .570 & .000 & .060 & -.081 & .152 \\
\hline $\begin{array}{l}\text { Overall Financial } \\
\text { Management } \\
\text { Practices }\end{array}$ & .060 & .344 & .000 & .057 & -.047 & .176 \\
\hline
\end{tabular}

The data shows that none of the two financial management practices, namely Personal or Family Budget $(r=0.054$, exact sig $=0.393)$ and Financial Decision-Making $(r=0.036$, exact $s i g=0.570)$, are significantly correlated with Financial Literacy. Further, the data showed that the Overall Financial Management Practices $(r=0.060$, exact sig $=0.344$ ) is also not significantly correlated with Financial Literacy. This particular finding had implications that they lack the application of their High Financial Literacy Level. This finding contradicts the study of Individuals who have less sophistication in financial literacy may not have a good grasp of the compounding of interests. They may engage in high-cost credit-card borrowing, or they are those who may be more likely to give higher fees when using financial services. As pointed out by Lusardi and Tufano (2009), they found that low literacy individuals are more likely to carry high-cost debt and to have problems with debt.

Further, another study found that analysis of scores on financial literacy and financial behavior or management indicates a consistent positive association between those two variables for each participating country. Respondents with higher financial literacy exhibit more positive financial behavior/management. The bootstrapped values affirmed the correlation result. 


\section{Degree of difference between the perspectives of the pastors and members on financial literacy and management practices}

\section{Table 5.1. Paired t-test between financial literacy and management}

practices by rank in the congregation (Bootstrapped, $n=1,000$ )

\begin{tabular}{lcccccc}
\hline & \multicolumn{3}{c}{ Original sample } & \multicolumn{3}{c}{ Bootstrapped $(\mathrm{n}=1,000)$} \\
$\begin{array}{l}\text { Rank in the } \\
\text { congregation }\end{array}$ & $\mathrm{t}$ & $\mathrm{df}$ & $\begin{array}{c}\text { Sig. } \\
(2-\text {-tailed })\end{array}$ & $\begin{array}{c}\text { Sig. } \\
(2-\text {-tailed })\end{array}$ & $\begin{array}{c}\text { 95\% Confidence Interval } \\
\text { Lower }\end{array}$ & Upper \\
\hline Leaders & 11.567 & 29 & .000 & .001 & .99040 & 1.44443 \\
Non-leaders & 12.431 & 30 & .000 & .001 & .86083 & 1.18963 \\
Member & 23.930 & 188 & .000 & .001 & .81433 & .96303 \\
\hline
\end{tabular}

Table 5.1 shows the paired t-test result between financial literacy and management practices by rank in the congregation. The table further showed the test result using the original sample size and the bootstrapped values.

The data showed that Financial Literacy and Management Practices significantly differed in each of the three groups in the congregation, namely Leaders $(t=11.567$, exact $s i g=0.000)$, Non-Leaders between financial literacy and management practices by rank in the congregation $(\mathrm{t}=12.431$, exact sig=0.000), and Members $(\mathrm{t}=23.930$, exact sig=0.000). The bootstrapped values affirm the result.

6. Is there a significant degree of difference between the two dimensions of financial management?

\section{Table 6.0. Paired t-test between personal/family budget and Financial decision-making}

\begin{tabular}{|c|c|c|c|c|c|c|}
\hline \multirow[b]{3}{*}{ Variable Pair } & \multicolumn{3}{|c|}{ Original sample $(n=250)$} & \multicolumn{3}{|c|}{ Bootstrapped $(n=1,000)$} \\
\hline & & & Siq. & Sig. & $95 \%$ Co & nce Interval \\
\hline & $\mathrm{t}$ & Df & (2-tailed) & & Lower & Upper \\
\hline \multicolumn{7}{|l|}{$\begin{array}{l}\text { Personal/ } \\
\text { family budget } \\
\text { vs. }\end{array}$} \\
\hline $\begin{array}{l}\text { VS. } \\
\text { Financial } \\
\text { Decision- } \\
\text { making }\end{array}$ & -12.143 & 249 & .000 & .001 & -.47680 & -.35120 \\
\hline
\end{tabular}


Table 6.0 shows the paired t-test result between financial management practice on Personal/family budget and Financial Decision-Making. Similar to the previous data tables, the test result using the original sample size and the bootstrapped values are shown in Table 8.0.

Both the paired $t$-test (t-test $=-12.143$, exact sig=0.000) result using the original sample size and the bootstrapped values (Lower and Upper Bound of the $95 \% \mathrm{Cl}-0.47680$ and -0.35120 , respectively) show significant differences between the financial management practice on Personal/ Family Budget and Financial Decision-Making.

\section{CONCLUSIONS}

The respondents have high financial literacy level, moderate level of their overall financial management. A closer look at their financial management revealed that they have moderate financial decision-making level. However, they have less financial management on a personal/family budget.

It was found that age groupings, civil status, educational attainment, employment status, are significantly associated with the level of financial literacy. No association exists between the respondents' financial literacy level and their sex.

As to the Age Groups, Employment, Personal/family budget, FHT revealed a statistically significant association that exists between the two variables.

As to the sex, civil status, education, and rank of the Congregation have no statistically significant association to personal/family budget; the data showed no statistically significant association between the two variables.

As to the association between age groups, sex, civil status, highest educational attainment, employment status, and the level of financial decision-making literacy, the FHT results revealed a statistically significant relationship that exists among the variables.

As to the Rank in the Congregation in relation to the Level of Financial Decision-Making Literacy Level of the respondents, no statistically significant relationship exists between the two.

None of the two financial management practices, namely Personal/ Family Budget and Financial Decision-Making, are significantly correlated with Financial Literacy. Further, the data showed that Overall Financial 
Management Practices is also not significantly correlated with Financial Literacy.

Financial Literacy and Management Practices significantly differ in each of the three groups in the Congregation, namely Leaders, NonLeaders between financial literacy and management practices by rank in the Congregation. As to the degree of difference between the two dimensions of financial management, T-Test showed significant differences between the financial management practice on Personal/Family Budget and Financial Decision-Making.

\section{RECOMMENDATIONS}

To address the gaps in this particular research, the following recommendations are provided:

1. Although a High Financial Literacy Level surfaced in this specific study, a need to reorient the parishioners, particularly the church members in this particular topic. Included in the extensive and intensive modules will be the awareness of the conditions of acquiring credit cards, loans, POs, as well as the compounded interests with their non-payments.

2. A need to conduct a thorough financial management capacitybuilding among all the churchgoers, including the church leaders, those who assumed non-leadership roles and the church members as they have less financial management on personal/family budget. $A$ further need to educate men and women on financial literacy.

As to their personal/family budget, very extensive and intensive modules on financial management on how to address impulse buying, not living within the means where the expenditures are higher than the family income.

3. Further advocacy on teaching the parishioners on entrepreneurship and livelihood skills will be conducted. Such as backyard gardening as for personal consumption as a way of saving and an additional source of family income; hog or chicken raising or other farm animals, however, they need to be taught on cleanliness and sanitation. Organic farming has to be encouraged so that higher utilization of waste products without resorting to chemicals which is equivalent to hurting the environment and people. The synergy and cycle of positivity will transpire between humans and natural resources. 


\section{REFERENCES CITED}

Atkinson, A., \& Messy, F. A. (2012). Measuring financial literacy. Retrieved from https://bit.ly/2NslkNI, (accessed last 20 August 2019).

Chiteji, N. S., \& Stafford, F. P. (1999). Portfolio choices of parents and their children as young adults: Asset accumulation by African-American families. American Economic Review, 89(2), 377-380. Retrieved from https://bit.ly/2GqKF8f, (accessed last 16 April 2019).

Dewey, J. (1938). Experience and Education. New York: Macmillan.

Financial Literacy Survey: 2016 Results. Central Council for Financial Services Information Secretariat: Public Relations Department, Bank of Japan. Retrieved from https://bit.ly/2P6jemE, (accessed last 14 April 2019).

Garman, E. T., \& Forgue, R. E. (2000). Personal finance: the human resource manager: Caught in the middle. CUPA Journal, 45(1), 33-35.

Gecas, Viktor. 1989. "The Social Psychology of Self-Efficacy." Annual Review of Sociology 15:291-316.

Harris, I. M., Denise, P., \& Thomas, R.M. (1989). Experiential education for community development. In Denise, P. S \& Harris, I.M. (Eds.) Experiential education for community development, (pp.1-18). NY: Greenwood Press. Retrieved from https://bit.ly/2VHTM9H, (accessed last 16 April 2019).

Hassan Al-Tamimi, H. A., \& Anood Bin Kalli, A. (2009). Financial literacy and investment decisions of UAE investors. The Journal of Risk Finance, 10(5), 500-516. Retrieved from https://bit.ly/33FXQf7, (accessed last 20 August 2019).

Hilgert, M. A., Hogarth, J. M., \& Beverly, S. G. (2003). Household financial management: The connection between knowledge and behavior. Federal Reserve Bulletin, 309-322. Retrieved from https://bit. ly/2KFfODX, (accessed last 16 April 2019). 
Hogarth, J., Beverly, S. G., \& Hilgert, M. (2003). Patterns of financial behaviors: Implications for community educators and policymakers. Federal Reserve System Community Affairs Research Conference, pp. 1-22. Retrieved from https://bit.ly/2Dglwtw, (accessed last 16 April 2019).

Huston, S. J. (2010). Measuring financial literacy. Journal of Consumer Affairs, 44(2), 296-316. Retrieved from https://bit.ly/2X51L1z, (accessed last 16 April 2019).

Johnson, E., \& Sherraden, M. S. (2007). From Financial Literacy to Financial Capability smong Youth. J. Soc. \& Soc. Welfare, 34, 119. Retrieved from https://bit.ly/2UEx9GH, (accessed last 10 April 2019).

Joo, S. (2013). Personal Financial Wellness. Handbook of Consumer Finance Research, 21-33. doi:10.1007/978-0-387-75734-6_2. Retrieved from https://bit.ly/33MsNOy, (accessed last 21 August 2019).

Joo, S. (1998). Personal financial wellness and worker productivity. Unpublished doctoral dissertation, Virginia Polytechnic Institute and State University, Blacksburg.

Jurevičienè, D., \& Ivanova, O. (2013). Behavioural finance: theory and survey/Finansinè elgsena: teorija ir tyrimas. Mokslas-Lietuvos ateitis/ Science-Future of Lithuania, 5(1), 53-58. Retrieved from https://bit. ly/2Zd11r4, (accessed last 16 April 2019).

Lusardi, Annamaria, and Peter Tufano. (2009.) "Debt Literacy, Financial Experiences, and Overindebtedness," NBER Working Paper n. 14808.

Lusardi, A., \& Mitchelli, O. S. (2007). Financial literacy and retirement preparedness: Evidence and implications for financial education. Business economics, 42(1), 35-44. Retrieved from https:// bit.ly/2IsWxZJ, (accessed last 16 April 2019).

Lusardi, A., \& Mitchell, O. S. (2011). Financial literacy around the world: an overview. Journal of pension economics \& finance, 10(4), 497-508. 
Retrieved from https://bit.ly/2X16hOx, (accessed last 16 April 2019).

Lusardi, A., \& Mitchell, O. S. (2014). The economic importance of financial literacy: Theory and evidence. Journal of economic literature, 52(1), 5-44. Retrieved from https://bit.ly/2CpIWh6, (accessed last 16 April 2019).

Mahdavi, Mahnaz. 2012. Financial Literacy among Educated Women: Room for Improvement. Working Paper, Smith College. Retrieved from https://bit.ly/2InZ87a, (accessed last 16 April 2019).

Modigliani, Franco, and Richard Brumberg. 1954. Utility Analysis and the Consumption Function: An Interpretation of Cross-section Data. In Post-Keynesian Economics. Ed. K. Kurihara. New Brunswick, NJ: Rutgers University Press: 388-436. Retrieved from https://bit. ly/2VJWCuF, (accessed last 16 April 2019).

United Nations 2015. Sustainable Development Goals. Retrieved from https://bbva.info/2UEyWeN, (accessed last 16 April 2019).

Schuchardt, J., Hanna, S. D., Hira, T. K., Lyons, A. C., Palmer, L., \& Xiao, J. J. (2009). Financial literacy and education research priorities. Journal of Financial Counseling and Planning, 20(1). Retrieved from https:// bit.ly/2GpDGfw, (accessed last 16 April 2019).

Vitt, L. A., Anderson, C., Kent, J., Lyter, D. M., Siegenthaler, J. K., Ward, J. (2000). Personal finance and the rush to competence: Financial literacy education in the U.S. Retrieved from https://bit.ly/2GexqWO, (accessed last 16 April 2019).

Xiao, J. J. (2008). Applying behavior theories to financial behavior. In Handbook of consumer finance research (pp. 69-81). Springer, New York, NY. Retrieved from https://bit.ly/2kFS4IE, (accessed last 10 April 2019). 